\title{
Bullous eruption in a patient with scabies: rare presentation of a common disease
}

\author{
Zmiany pęcherzowe u pacjenta ze świerzbem - rzadka postać powszechnie \\ występującego schorzenia
}

\author{
Sabha Mushtaq', Mohammad Adil', Syed Suhail Amin', Mohammad Mohtashim', Fatima Tuz Zahra', Shagufta Qadri \\ 'Department of Dermatology, Jawahar Lal Nehru Medical College, Aligarh, UP, India \\ 2Department of Pathology, Jawahar Lal Nehru Medical College, Aligarh, UP, India \\ 'Klinika Dermatologii, Jawahar Lal Nehru Medical College, Aligarh, UP, Indie \\ ${ }^{2}$ Klinika Patologii, Jawahar Lal Nehru Medical College, Aligarh, UP, Indie
}

Dermatol Rev/Przegl Dermatol 2019, 106, 221-224 DOl: https://doi.org/|0.5||4/dr.2019.85580

Scabies is a contagious infestation caused by the mite Sarcoptes scabiei and affecting all races and social classes. It is a common parasitic infection; the diagnosis is trivial when presentation is classical. However, unusual clinical variants such as crusted, hidden, incognito, bullous and nodular forms may mimic non-parasitic dermatoses and pose a diagnostic challenge [1]. A high index of suspicion and demonstration of the mite and/or its eggs in such cases can help to clinch the diagnosis. Herein, we report a case of scabies presenting with bullous eruption.

A 35-year-old male presented with multiple blisters mainly over the upper extremity and axillae for 20 days. Blisters appeared over itchy erythematous skin and ruptured on scratching to leave behind raw areas which developed crusting and some healed with hypopigmentation. There was a history of generalised itching which preceded the bullous eruption by 10 days. It was more intensive during the night and affected other family members as well. The patient denied any history of drug intake. He was otherwise well and had no chronic illness.

General physical and systemic examination was within normal limits. Cutaneous examination revealed multiple tense vesicles and bullae filled with clear fluid present over an erythematous base on the upper limbs, axillae and upper back. Haemorrhagic crusting and areas of hypopigmentation suggestive of old healed lesions were also noted (figs. 1 A, B). Nikolsky's sign was negative. Excoriated papules were present over the abdomen and finger webs (figs. $1 \mathrm{C}$, D). Mucosal examination was normal. Scraping from the finger webs demonstrated scabies mite. Histopa-
Świerzb jest chorobą zakaźną skóry wywoływaną przez roztocze - świerzbowca ludzkiego (Sarcoptes scabiei). Choroba dotyczy wszystkich ras i klas społecznych. Świerzb jest częstym zakażeniem pasożytniczym, którego rozpoznanie w przypadku typowych objawów nie sprawia trudności. Nietypowe kliniczne postaci świerzbu, takie jak odmiana norweska, ukryta, incognito, pęcherzowa i guzkowa, mogą jednak naśladować dermatozy niepasożytnicze i stanowić wyzwanie diagnostyczne [1]. W takich przypadkach ustalenie rozpoznania ułatwia obraz kliniczny nasuwający podejrzenie oraz stwierdzenie obecności roztoczy i/lub ich jaj. Opisujemy przypadek 35-letniego mężczyzny ze świerzbem objawiającym się pęcherzowymi wykwitami skórnymi.

U pacjenta stwierdzono rozsiane zmiany pęcherzowe umiejscowione głównie na kończynach górnych i w dołach pachowych, utrzymujące się od 20 dni. Pęcherze powstały na skórze zmienionej rumieniowo, zmianom towarzyszył świąd. Wskutek drapania pęcherze pękały i tworzyły się nadżerki, a następnie strupy i niekiedy odbarwienia. W wywiadzie występował uogólniony świąd, który poprzedzał pojawienie się wykwitów pęcherzowych o 10 dni. Dolegliwości świądowe były bardziej nasilone w nocy i występowały również u innych członków rodziny. Pacjent negował przyjmowanie leków. Poza stwierdzonymi objawami mężczyzna był zdrowy i nie leczył się z powodu żadnych chorób przewlekłych.

Badanie ogólne nie wykazało odchyleń od stanu prawidłowego. W badaniu przedmiotowym stwierdzono mnogie, napięte pęcherzyki i pęcherze wypełnione przejrzystym płynem, umiejscowione na podłożu rumieniowym w obrębie kończyn górnych, dołów 

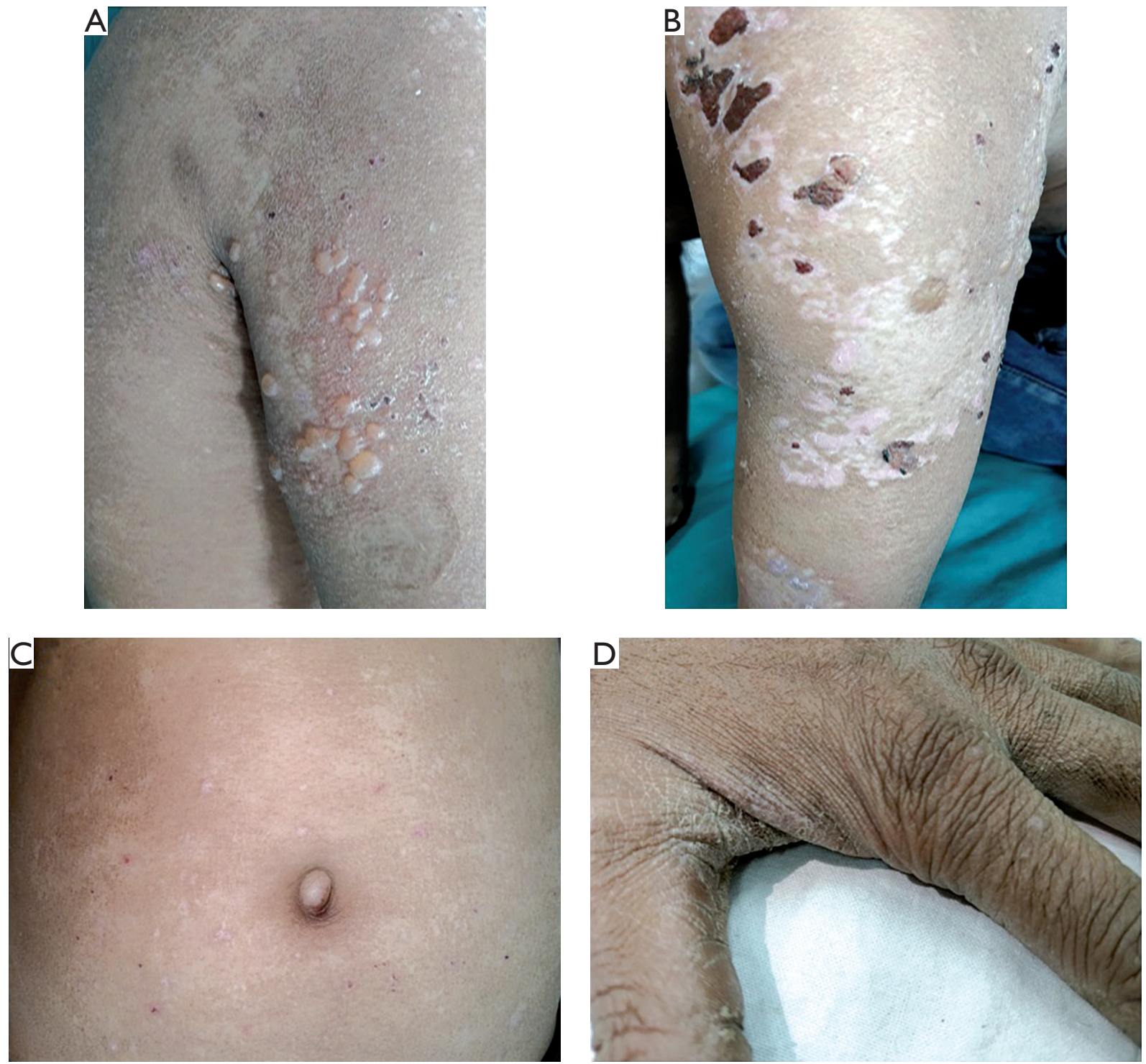

Figure I. A - Multiple tense vesicles and bullae present over a background of erythema over the upper back. B - Crusted erosions and hypopigmentation over the arm. $\mathbf{C}$ - Excoriated papules over the abdomen. $\mathbf{D}$ - Involvement of finger webs

Rycina I. A - Liczne, napięte pęcherzyki i pęcherze na podłożu rumieniowym umiejscowione w górnej części pleców. B - Pokryte strupem nadżerki i hipopigmentacja na skórze ramienia. C - Przeczosy na skórze brzucha. D - Zajęcie przestrzeni między palcami rąk

thology of the bulla revealed a subepidermal split with inflammatory infiltrate comprising of lymphocytes and eosinophils (figs. 2 A, B). Immunofluorescence could not be performed due to financial constraints. Diagnosis of bullous scabies was made and the patient was given $5 \%$ permethrin lotion for local application and antihistamines. Pruritus improved but bullous lesions continued to appear. Oral steroids were then administered in tapering doses with healing of the bullous lesions and remission in the appearance of fresh lesions.

Scabies classically presents with nocturnal pruritus and pleomorphic skin lesions as burrows, excoriated papules, nodules and as thick crusted plaques in crusted scabies. Impetigo, folliculitis, eczematisation pachowych i górnej części pleców. Obserwowano także strupy krwotoczne i ogniska hipopigmentacji wskazujące na obecność dawnych, wygojonych zmian skórnych (ryc. 1 A, B). Objaw Nikolskiego był ujemny. Na skórze brzucha i w przestrzeniach między palcami rąk stwierdzono przeczosy (ryc. 1 C, D). W obrębie błon śluzowych nie wykazano żadnych nieprawidłowości. W zeskrobinach skóry z przestrzeni między palcami obecne były świerzbowce. W badaniu histopatologicznym stwierdzono podnaskórkowy pęcherz z naciekiem zapalnym złożonym z limfocytów i eozynofilów (ryc. 2 A, B). Z powodu ograniczeń finansowych nie można było przeprowadzić badania immunofluorescencyjnego. Ustalono rozpoznanie świerzbu pęcherzowego, a pa- 

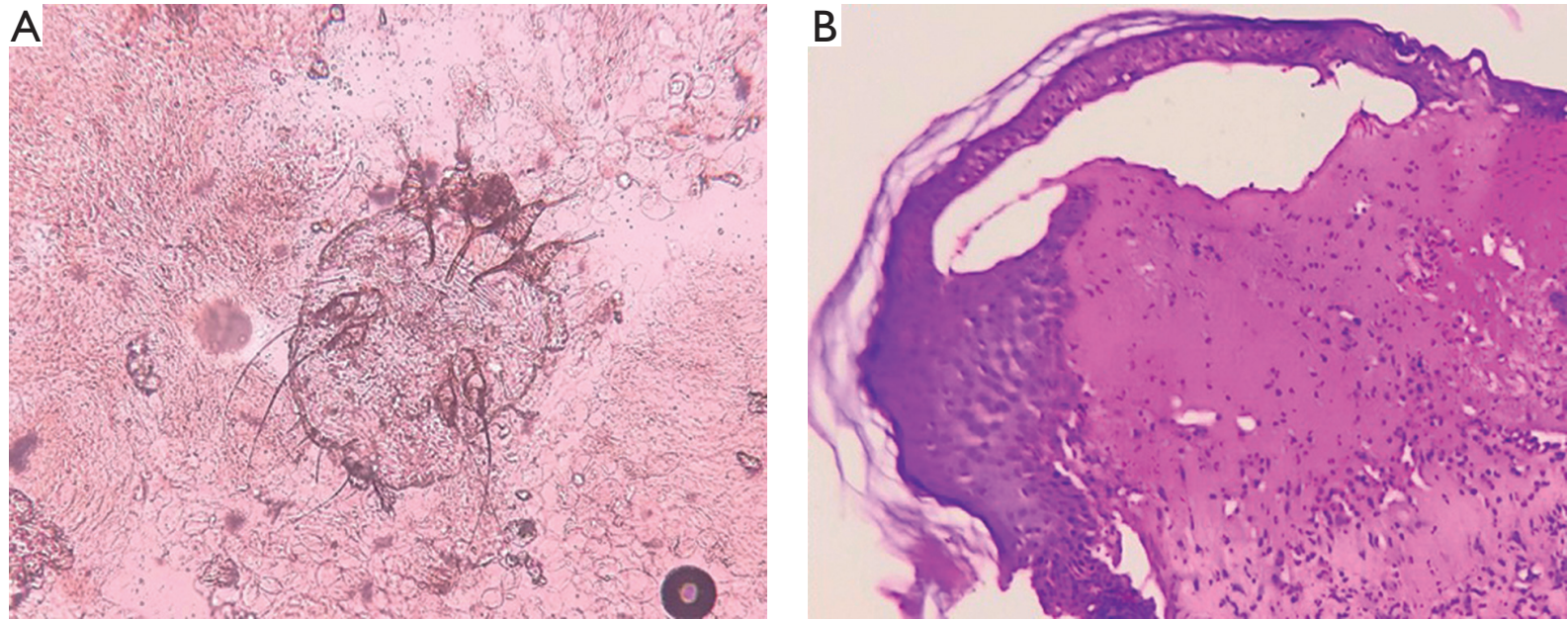

Figure 2. A - KOH mount showing scabies mite. B - Skin biopsy showing a sub-epidermal bulla with inflammatory infiltrate of lymphocytes and eosinophils in the dermis (H\&E, I00X)

Rycina 2. A - Badanie wodorotlenkiem potasu $(\mathrm{KOH})$ - widoczne świerzbowce. B - Wycinek skóry - pęcherz podnaskórkowy z naciekiem zapalnym złożonym z limfocytów i eozynofilów w skórze właściwej (barwienie H\&E, powiększenie I00×)

and urticaria can occur as complications. Bullous lesions in a case of scabies are less frequent [1].

Bullous scabies is a rare presentation of Sarcoptes scabiei infestation. It may mimic bullous pemphigoid both clinically and histologically. Direct immunofluorescence often reveals deposition of immunoglobulins and complement at the basement membrane zone (BMZ) similar to bullous pemphigoid [2]. The cause underlying bulla formation in scabies is not clear but various mechanisms have been proposed. Staphylococcus aureus superinfection of scabietic lesions may result in bulla formation by a mechanism similar to bullous impetigo [3]. Another hypothesis is auto-antibody mediated damage to the BMZ. The auto-antibody production is elicited either due to antigenic mimicry between mite antigens and BMZ antigens or due to exposure of the BMZ-like antigens by lytic enzymes released by the mite [4,5]. Konishi et al. demonstrated circulating antibodies against BP180 and/or BP230 by western blot analysis in two scabietic patients and proposed that the bullous eruption in at least some scabies cases may be true bullous pemphigoid [6]. We cannot comment on the pathogenic mechanism responsible for bulla formation in our case as no antibody test could be performed. In patients where bullae are located entirely on sites where scabietic lesions are present, the role of type I immune response has been suggested [4].

Whatever the mechanism, the skin lesions consist of widespread pruritic tense vesicles and bullae filled with clear or sometimes haemorrhagic fluid. The treatment is similar to classical scabies with $5 \%$ permethrin, ivermectin. Some cases require systemic steroids as in our patient and this cjentowi przepisano płyn zawierający 5\% permetryny do stosowania miejscowego oraz leki przeciwhistaminowe. Nasilenie świądu zmniejszyło się, jednak na skórze nadal pojawiały się zmiany pęcherzowe. Do leczenia wprowadzono doustne glikokortykosteroidy ze stopniową redukcją dawki. Wykwity pęcherzowe wygoiły się, nie pojawiły się nowe zmiany.

Klasyczna postać świerzbu charakteryzuje się nocnym świądem oraz występowaniem wielopostaciowych zmian skórnych, takich jak swędzące grudki, przeczosy, guzki oraz grube strupy (w przypadku świerzbu norweskiego). Opisywano jako powikłania wtórne zakażenie bakteryjne, zapalenie mieszków włosowych, wyprysk i pokrzywkę. Zmiany pęcherzowe w przebiegu świerzbu są mniej typowe [1].

Świerzb pęcherzowy stanowi rzadką postać kliniczną infekcji świerzbowcem ludzkim. Ta odmiana choroby może naśladować pemfigoid pęcherzowy zarówno pod względem klinicznym, jak i histologicznym. Badanie metodą immunofluorescencji bezpośredniej często wykazuje obecność złogów immunoglobulin i dopełniacza w strefie błony podstawnej (BMZ), podobnie jak $\mathrm{w}$ przebiegu pemfigoidu [2]. Przyczyna powstawania pęcherzy w przebiegu świerzbu nie została dokładnie wyjaśniona, a w piśmiennictwie postuluje się różne mechanizmy leżące u podstaw tego procesu. Nadkażenie zmian gronkowcem złocistym może powodować powstawanie pęcherzy w mechanizmie podobnym do liszajca pęcherzowego [3]. Inna hipoteza zakłada uszkodzenie BMZ przy udziale autoprzeciwciał. Wytwarzanie autoprzeciwciał następuje albo wskutek zjawiska mimikry antygenowej pomiędzy antygenami roztoczy $i$ błony podstawnej, albo w efekcie ekspozycji antygenów podobnych do BMZ przez enzymy lityczne 
supports the immune mediated mechanism of bulla formation [1].

Bullous scabies is a rare occurrence which may resemble various immunobullous disorders causing a diagnostic dilemma. Scabies should therefore be suspected in a patient with generalised pruritus and bullous lesions so that the patients are not exposed to unnecessary investigations and ineffective treatments.

\section{CONFLICT OF INTEREST}

The authors declare no conflict of interest. uwalniane przez roztocza [4, 5]. Konishi i wsp. metodą Western blot wykazali obecność krążących przeciwciał przeciwko antygenom BP180 i/lub BP230 u dwóch pacjentów ze świerzbem. Badacze wysunęli hipotezę, że osutka pęcherzowa przynajmniej w niektórych przypadkach świerzbu może być objawem pemfigoidu pęcherzowego [6]. Mechanizm patogenny odpowiedzialny za powstawanie pęcherzy w opisywanym przez nas przypadku nie został ustalony ze względu na brak możliwości oznaczenia przeciwciał. U chorych, u których pęcherze są umiejscowione wyłącznie na zmianach świerzbowcowych, wskazywano na potencjalną rolę odpowiedzi immunologicznej typu I [4].

Niezależnie od mechanizmu powstawania zmiany skórne mają postać rozległych, swędzących, napiętych pęcherzyków i pęcherzy wypełnionych surowiczą, a niekiedy krwotoczną treścią. Leczenie jest podobne jak w klasycznej postaci świerzbu - permetryna 5\%, iwermektyna. Niektórzy pacjenci wymagają stosowania glikokortykosteroidów podawanych ogólnie. Może to świadczyć o zależnym od układu immunologicznego mechanizmie powstawania pęcherzy [1].

Świerzb pęcherzowy występuje rzadko i może naśladować różne autoimmunologiczne choroby pęcherzowe, co powoduje trudności diagnostyczne. W diagnostyce różnicowej zmian skórnych u pacjentów z uogólnionym świądem i zmianami pęcherzowymi należy uwzględnić również świerzb, aby uniknąć niepotrzebnych badań i nieskutecznego leczenia.

\section{KONFLIKT INTERESÓW}

Autorzy nie zgłaszają konfliktu interesów.

\section{References}

\section{Piśmiennictwo}

1. Ansarin H., Jalali M.H., Setarehshenas R., Mazloomi S., Soltani-Arabshahi R.: Scabies presenting with bullous pemphigoidlike lesions. Dermatol Online J 2006, 12, 19.

2. Gutte R.M.: Bullous scabies in an adult: a case report with review of literature. Indian Dermatol Online J 2013, 4, 311-313.

3. Herman P.S.: Letter: scabies and bullae. JAMA Dermatol 1975, 231, 1134.

4. Maan M.A., Maan M.S., Sohail A.M., Arif M.: Bullous scabies: a case report and review of the literature. BMC Res Notes $2015,8,254$.

5. Veraldi S., Scarabelli G., Zerboni R., Pelosi A., Gianotti R.: Bullous scabies. Acta Derm Venereol 1996, 76, 167-168.

6. Konishi N., Suzuki K., Tokura Y., Hashimoto T., Takigawa M.: Bullous eruption associated with scabies: evidence for scabetic induction of true bullous pemphigoid. Acta Derm Venereol 2000, 80, 281-283.

Received: 26.11 .2018

Accepted: 30.03 .2019

Otrzymano: $26.11 .2018 \mathrm{r}$.

Zaakceptowano: $30.03 .2019 \mathrm{r}$.

How to cite this article

Mushtaq S., Adil M., Amin S.S., Mohtashim M., Zahra F.T., Qadri S.: Bullous eruption in a patient with scabies: rare presentation of a common disease. Dermatol Rev/Przegl Dermatol 2019, 16, 221-224. DOI: https://doi.org/10.5114/dr.2019.85580. 